\title{
Klasszikus és módosított fogtőgörbe összehasonlító vizsgálata
}

\section{A Comparison between a Classical and a Modified Root Fillet}

\author{
Hodgyai Norbert, ${ }^{1}$ Tolvaly-Roșca Ferenc, ${ }^{2}$ Máté Márton ${ }^{3}$ \\ Sapientia Erdélyi Magyar Tudományegyetem, Marosvásárhelyi Kar, Gépészmérnöki Tanszék, \\ Marosvásárhely, Románia \\ ${ }^{1}$ hodgyai@ms.sapientia.ro \\ ${ }^{2}$ tferi@ms.sapientia.ro \\ ${ }^{3}$ mmate@ms.sapientia.ro
}

\begin{abstract}
The main purpose of this paper consists in improving the rigidity of the gear tooth by applying various root fillet forms that differ from the classical $0.38 \mathrm{~m}$ radius circle arc. During the research the necessity of the re-formulation of the undercut appeared. It appears much later in case of applying rounded addendum edge planing comb as in case of using a classic generating profile tool. Therefore, the limits of the profile shifting can be significantly extended without weakening the tooth dedendum.

The paper presents the stress repartitions under equal load, which occur on classic teeth, and on teeth having a modified root fillet. In this last case, the modified root fillet is the envelope of the curve family constituted by the rounded edge curves, in the relative motion of the comb related to the cut gear.
\end{abstract}

Keywords: gear, root fillet,stress analysis, deformation, rigidity.

\section{Összefoglalás}

A kutatásunk célja, hogy a szabványos 0,38m sugarú körívvel közelített foglábgörbétől eltérő foglábgörbéket használva javítsuk a fog merevségét. A kutatás során fény derült az alámetszési probléma újra értelmezésének szükségére, mivel a lekerekített fejü fésűskéssel sokkal kisebb fajlagos profileltolás-értékekre jelenik meg az alámetszés, mint a hegyes elméleti szerszám esetében, így jóval nagyobb profileltolásokat alkalmazhatunk, mint korábban, a fog radikális gyengítését elkerülve. A dolgozatban azt tárgyaljuk, hogy a lefejtő fogasléc lekerekített fejének burkológörbéjét használva foglábgörbeként, a deformációk különböznek-e a hagyományos szerszámmal generált fogaskerekék deformációitól a terhelésekor.

Kulcsszavak: fogaskerék, foglábgörbe, terhelésanalízis, deformáció, merevség.

\section{Bevezetés}

Az evolvensgörbe generálása szempontjából a hengeres kerekek lefejtő szerszámai két csoportba sorolhatók:

- az álló egyenes módszerével generáló szerszámok - ezek a fésűskések;

- a mozgó egyenes módszerével generáló szerszámok - a csigamaró, a metszőkerék és a hámozókerék [1].
Az evolvens fogprofilú fogaskerék gyártása fogasléc alakú szerszámmal a legpontosabb, mivel a léc-kerék kinematikai kapcsolat egyenértékű a körön legördített egyenes mozgásával, az egyenes élalak pedig mindig pontosabban előállítható, mint a görbült felületekről származó élek. Tehát, ha a gyártandó kerék osztókörén a szerszám osztóvonalát csúszásmentesen legördítjük, akkor a fogasléc fogprofil-merőleges mindig az alapkörön 
gördül le, és a különböző helyzetekbe kerülő élnyomok seregét burkoló görbe a lefejtett kerék fogprofilja lesz. Ebben az esetben a fogasléc fogai egyszerü trapéz alakúak. Többek között emiatt terjedt el az evolvens fog használata, mivel a fogasléc alakú fogazószerszámokat egyszerűen és nagy pontossággal lehet gyártani, ezzel ellentétben a szerszámgép kinematikája a lehető legbonyolultabb.

Az evolvens profilú hengeres kerekek lefejtő fogaslécének alapprofilja, a DIN 867-1986 szerint, az 1. ábrán látható.

A kutatási célnak megfelelően, a lehető legpontosabban generáló szerszámot választjuk alapul, majd a szerszám fejének lekerekítését módosítjuk. A módosított fogfejü szerszámmal generált profilt és a szabványos profilt azonos körülmények közt terheljük (anyagminőség, terhelési erő, a virtuális térben azonos rögzítési bázisfelület). Terhelési analízist alkalmazunk, hogy vizsgáljuk az általunk javasolt fogprofillal gyártott fog viselkedését, a gyakorlatban alkalmazott, kisebb lekerekítésű szerszámmal előállított fogazathoz viszonyítva.

\section{A matematikai modell}

\subsection{A foglábgörbe egyenletei}

A fogazási eljárás matematikai modelljének felépítéséhez szükséges geometriai alapmodell a 2. ábrán látható.

A fogazószerszám fogprofilja a tengelytávvonalhoz viszonyítva szimmetrikus alaphelyzetben található. Az ábrán a következő 5 koordinátarendszert tüntettük fel:

$-X_{0} P Y_{0}$ - a rögzített koordinátarendszer, amelynek $\mathrm{P}$ origója a léc-kerék virtuális hajtás főpontjában található, így a $P X_{0}$ tengely érinti a gördülőkört:

- $X_{1}^{(0)} O_{1}^{(0)} Y_{1}^{(0)}$ - a léchez rögzített koordinátarendszer, alaphelyzetben;

$-X_{1} O_{1} Y_{1}-$ a léchez rögzített koordinátarendszer, miután a fogazandó kerék $\varphi$ szöggel elfordult a fogazás során;

- $X_{2}^{(0)} O_{2}^{(0)} Y_{2}^{(0)}$ - a fogazandó kerékhez rögzített koordinátarendszer, alaphelyzetben;

$-\mathrm{X}_{2} \mathrm{O}_{2} Y_{2}$ - a fogazandó kerékhez rögzített koordinátarendszer, miután a kerék $\varphi$ szöggel elfordult a fogazás során.

A fogazási eljárás alatt a fogazószerszám eltávolítja a szerszámprofil körvonalán belül található anyagot. Ezt a modellezés során úgy értelmezzük, hogy a profil, amely kialakul az előgyártmányon, az a fogazószerszám éleinek burkológörbéje.

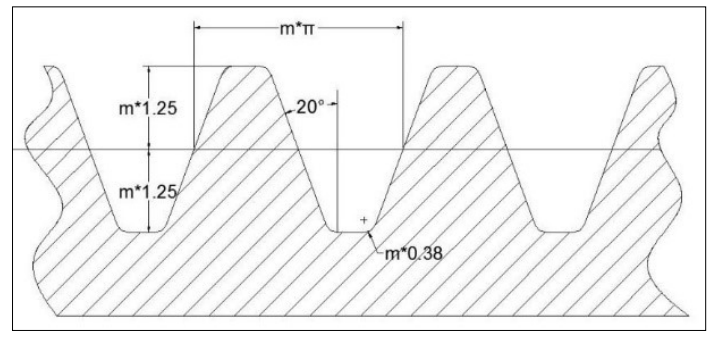

1. ábra. A lefejtő fogasléc

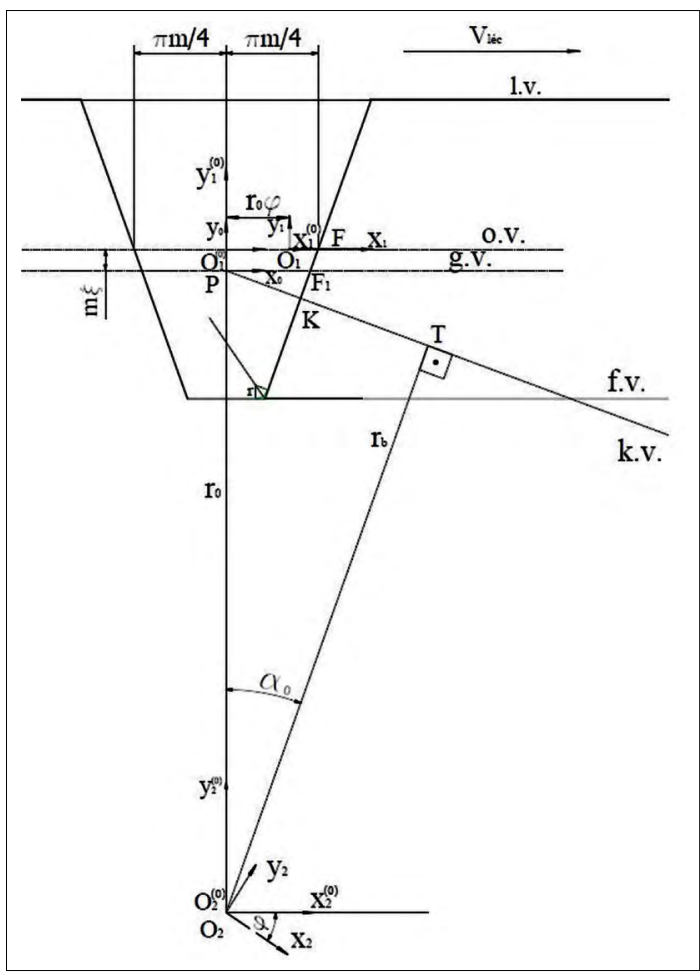

2. ábra. A lefejtés geometriája

A fogprofil egyenleteinek kiszámításához a fogaskerék rendszerében kell dolgoznunk a továbbiakban.

A lefejtő léc profilját a saját rendszerében tudjuk a legkönnyebben felírni, majd a fogaskerék rendszerébe transzformáljuk az alábbi módon:

$$
\mathbf{r}_{2}=\mathbf{M}_{21} \mathbf{r}_{1}
$$

A számítások elvégzése után a transzformációs mátrix alakja a következő lesz:

$$
\begin{aligned}
\mathbf{M}_{21} & =\left(\begin{array}{cccc}
\cos \varphi & -\sin \varphi & 0 & a_{14} \\
\sin \varphi & \cos \varphi & 0 & a_{24} \\
0 & 0 & 1 & 0 \\
0 & 0 & 0 & 1
\end{array}\right), \\
a_{14} & =r_{0} \varphi \cos \varphi-\left(r_{0}+m \xi\right) \sin \varphi \\
a_{24} & =r_{0} \varphi \sin \varphi+\left(r_{0}+m \xi\right) \cos \varphi
\end{aligned}
$$


A kapcsolódási egyenletet [2] a gyártóléc koordinátarendszerében írjuk fel és oldjuk meg:

$$
\mathbf{v}_{1}{ }^{(12)} \times \mathbf{n}_{1}=0
$$

A (3) egyenletben szereplő mennyiségek kifejezései sorban a következők, $\omega=-1$-re:

$$
\begin{aligned}
& \mathbf{v}^{(12)}=\mathbf{v}^{(1)}-\mathbf{v}^{(2)} \\
& \mathbf{v}_{1}^{(1)}=\left(\begin{array}{lll}
r_{0} \omega & 0 & 0
\end{array}\right)^{T}=\left(\begin{array}{lll}
r_{0} & 0 & 0
\end{array}\right)^{T} \\
& \underline{\mathbf{v}}_{1}^{(2)}=\left[\begin{array}{c}
y_{1}+r_{0}+m \xi \\
-x_{1}-r_{0} \varphi \\
0
\end{array}\right]
\end{aligned}
$$

A normális vektor $\left(n_{x} n_{y} 0\right)$ összetevőivel a léc-kerék kapcsolódási egyenlet általános alakja a következő:

$$
\left(y_{1}+m \xi\right) n_{x}+\left(x_{1}+r_{0} \varphi\right) n_{y}=0
$$

A kapcsolódási egyenletet a foglábgörbe analitikus felírására használjuk fel. A koordinátarendszerek helyzete a 3 . ábrán látható. A gyártóléc lekerekített profiljának egyenletei, a léc rendszerében a következők:

$$
\left\{\begin{array}{l}
x_{1}(u)=x_{C}+r \cos \left(\alpha_{0}+u\right) \\
y_{1}(u)=y_{C}-r \sin \left(\alpha_{0}+u\right)
\end{array}\right.
$$

A körív normálvektorának koordinátái:

$$
\underline{\mathbf{n}}(u)=\left(\begin{array}{lll}
\cos \left(\alpha_{0}+u\right) & \sin \left(\alpha_{0}+u\right) & 0)^{T}
\end{array}\right.
$$

A körív alakú lekerekítés határainak számítása részletesen megtalálható a [3]-ban. A lekerekítési sugár legnagyobb lehetséges értékét abból a feltételből számítjuk ki, hogy ennek fogmagasság-irányú terjedelme ne lépje túl a $c=0,25 \mathrm{~m}$ szabványos foglábhézagértéket. Ennek alapján a legnagyobb lehetséges fajlagos sugár értéke

$$
r_{\max }^{*}=\frac{c_{0}}{\cos \alpha_{0}} \operatorname{tg}\left(\frac{\pi}{4}+\frac{\alpha_{0}}{2}\right)
$$

A fentiek alapján, a lefejtő léc fejének lekerekítési sugarát az

$$
r=m \psi r_{\text {max }}, \psi \in(0,1)
$$

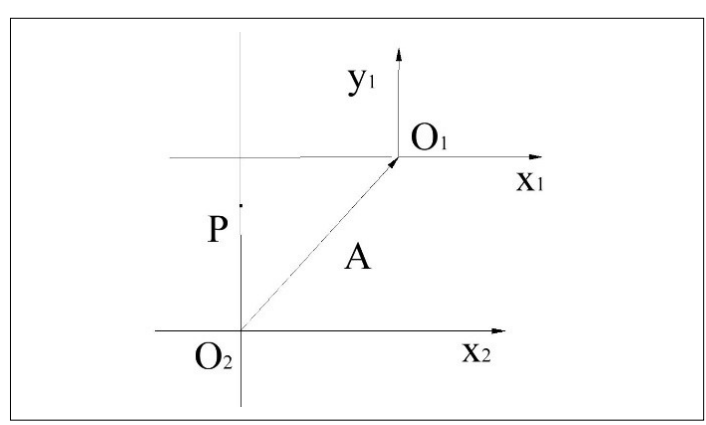

3. ábra. A koordinátarendszerek helyzete

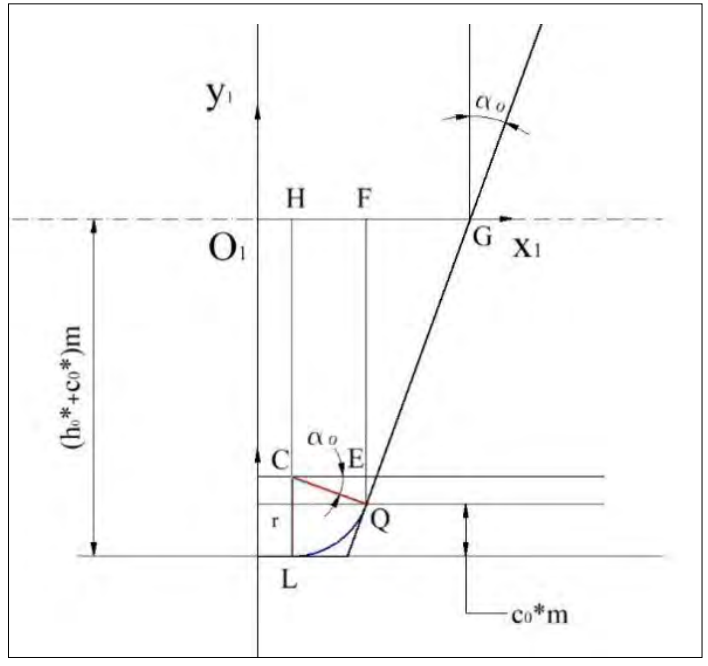

4. ábra. A C-középpont koordinátáinak számítása

képlettel számoljuk. A kerekítési ív központjának koordinátái [3] pedig (4. ábra):

$$
\left\{\begin{array}{l}
x_{1}^{C}=m\left(\frac{\pi}{4}-\left(h_{0}^{*}+c_{0}^{*}\right) \operatorname{tg} \alpha_{0}-\frac{\psi r^{*}}{\cos \alpha_{0}}\right) \\
y_{1}^{C}=\left(\psi r^{*}-\left(h_{0}^{*}+c_{0}^{*}\right)\right) m
\end{array}\right.
$$

A foglábgörbét kialakító burkolt görbesereg egyenleteit az (1), (2) és (8) képletekből számítjuk. A műveletek elvégése után ezek a következők lesznek:

$$
\left\{\begin{array}{l}
x_{2}(u, \varphi)=A \cos \varphi+B \sin \varphi-r_{0}(\sin \varphi-\varphi \cos \varphi)- \\
\quad-m \xi \sin \varphi \\
y_{2}(u, \varphi)=A \sin \varphi+B \cos +r_{0}(\cos \varphi+\varphi \sin \varphi)+ \\
\quad+m \xi \cos \varphi \\
A=x_{C}+r \cos \left(\alpha_{0}+u\right) \\
B=y_{C}-r \sin \left(\alpha_{0}+u\right)
\end{array}\right.
$$

A (7) kapcsolódási egyenlet a (9) normálvektor-koordinátákkal homogén trigonometriai egyenletté egyszerüsödik, melynek megoldása [3]

$$
u(\varphi)=\left\{\begin{array}{l}
-\operatorname{arctg}(g(\varphi))-\alpha_{0}+\pi, \varphi \leq \varphi_{k r} \\
-\operatorname{arctg}(g(\varphi))-\alpha_{0}, \varphi>\varphi_{k r}, \\
g(\varphi)=\left(y_{1}^{C}+m \xi\right) /\left(x_{1}^{C}+r_{0} \varphi\right)
\end{array}\right.
$$

\subsection{A foglábgörbe és az evolvens szakasz érintkezési pontjának vizsgálata}

A foglábgörbe parametrikus egyenletei, a kapcsolódási egyenlet megoldásának alakja miatt, meglehetősen bonyolultak és nem egyszerűen alkalmazhatók. A testmodell előkészítése céljából szükséges meghatározni az elméleti evolvens fog- 
profil és a valós foglábgörbe érintkezési pontját, amely a talpkörön illeszkedik. A lekerekített generáló fogasléc esetében is lehet a [4]-ben alkalmazott geometriai szerkesztést alkalmazni. Jelen tanulmányban csak azon esetek elemzésére összpontosítunk, amelyek az alámetszés határa fölött vannak, tehát a fogláb és az evolvensgörbe érintők, nem pedig metszők.

\subsubsection{Az evolvens geometriai felírása}

Az „A, pontot a lefejtő szerszám „A” pontja generálja, az „A $\mathrm{A}_{2}$ ” pontot pedig az egyenes élszakasz első pontja generálja (5. ábra). Mivel az egyenes szakasz végpontja és a körívszakasz kezdőpontja egybeesnek, valamint a két görbe csatlakoztatott, az adott pontban van közös érintőjük, tehát közös normálisuk is. Ez azt jelenti, hogy a burkolóprofilon a két görbe egy időben hozza létre a megfelelő pontot.

\subsubsection{A talpkör kiszámítása a kapcsolóvonal alapján}

Az 6 ábrán a $P B E$-tengelyvonal és a kapcsolóvonalra ennek $\mathrm{T}$ pontjából emelt merőleges a kerék $O_{2}$-középpontjában metszik egymást, tehát $O P=r_{0}$ és $O T=r_{b}$.

Az 6. ábrán felismerhető geometriai összefüggésekből:

$$
\begin{aligned}
& P B=m\left(h_{0}+c_{0}-\xi\right)-m \psi r^{*}\left(1-\sin \alpha_{0}\right) \\
& A A_{1}=B A_{1}-B A=m\left(h_{0}+c_{0}-\xi-\psi r^{*}\right) \operatorname{ctg} \alpha_{0}
\end{aligned}
$$

Innen az A pont kapcsolásának megfelelő legördülési szög értéke

$$
\varphi_{A}=\frac{A A_{1}}{r_{0}}=\frac{2\left(h_{0}+c_{0}-\xi-\psi r^{*}\right) \operatorname{ctg} \alpha_{0}}{Z}
$$

A talpkör sugarát a [4] alapján és a 6. ábrán használt jelölésekkel az $O T A_{1}$ háromszögből számítottuk ki. A számítás részletezésétől eltekintünk.

Az elméleti evolvens matematikai generálásából (7. ábra) származtatott egyenletek a következők

$$
\left\{\begin{array}{l}
x(v)=r_{b}(\sin (\varepsilon+v)-v \cos (\varepsilon+v)) \\
y(v)=r_{b}(\cos (\varepsilon+v)+v \sin (\varepsilon+v))
\end{array}\right.
$$

Az $\varepsilon$ szög az alapköri fogárokív félszögét jelzi:

$$
\varepsilon=\frac{\pi}{2 z}-2 \frac{\xi}{z} \operatorname{tg} \alpha_{0}-i n v \alpha_{0}
$$

Ismervén az $r_{t}$-alapkörsugár-értéket, a (17) egyenletekből kiszámítjuk a $\mathrm{u}$ paraméter intervallumát:

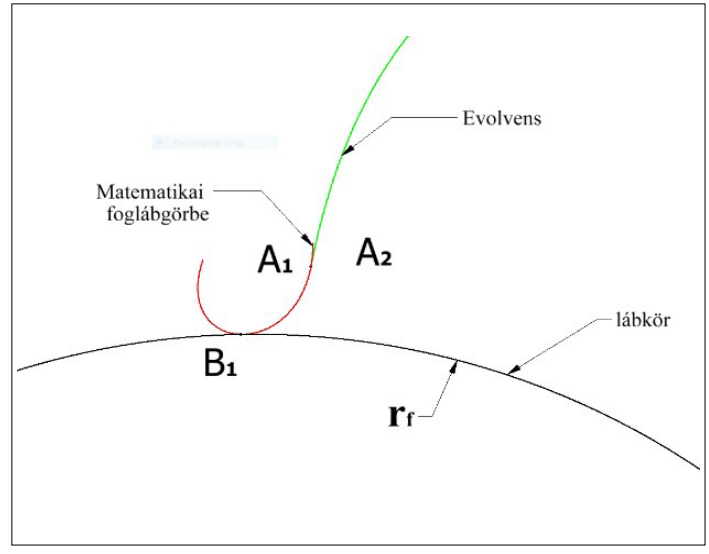

5. ábra. A körív által generált foglábgörbe csatlakozása az evolvenshez és a lábkörhöz

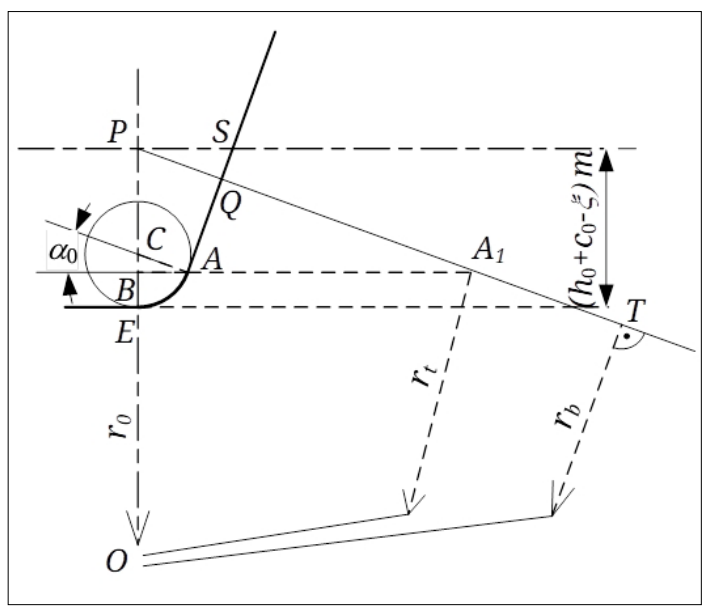

6. ábra. A talpkörsugár értelmezése a lekerekített szerszám esetében

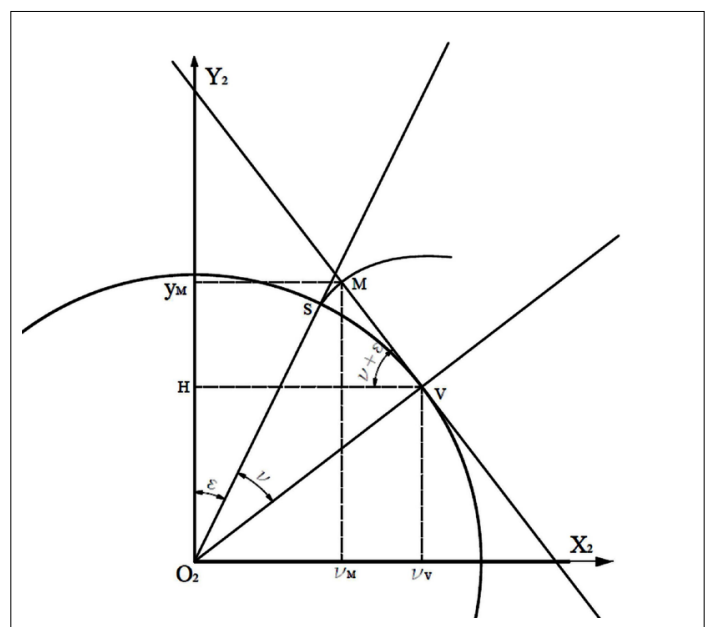

7. ábra. Az evolvens matematikai generálásához használt ábra 


$$
r_{t} \leq r_{x} \leq r_{a} \Leftrightarrow \sqrt{\frac{r_{t}^{2}}{r_{b}^{2}}-1} \leq \varepsilon \leq \sqrt{\frac{r_{a}^{2}}{r_{b}^{2}}-1}
$$

Szintén a 6. ábra alapján kijelenthetjük, hogy a mozgásparaméter nulla értékének megfelelő alaphelyzetben nemcsak az egyenes profil $Q$ pontja kapcsol, hanem az $A E$ körív $A$ pontja is.

Az ábráról ki lehet következtetni, hogy a foglábgörbe burkolása és az evolvens fogoldal burkolása egyidejüleg történik: míg az evolvens profil a kisebb polársugarú pontok irányában alakul ki, a foglábgörbe a lábkörtől, a talpkör tehát a polársugarak növekedésének irányában.

Innen következtetünk, hogy a foglábgörbét a burkoló (14) és (16) egyenleteiből írjuk fel, úgy, hogy a $\varphi$ paramétert a $\left[0, \varphi_{\mathrm{A}}\right]$ intervallumban futtatjuk.

\subsection{A generált görbék bemutatása}

A 8. ábrán látható görbe felrajzolását a megadott egyenletek alapján a Mathcad 15 szoftverben végeztük, ahol első lépésben definiáltuk a kezdeti paramétereket. A fogaskerék választott paraméterei a következők voltak:

-modul: $50 \mathrm{~mm}$,

-alapprofilszög: $20^{\circ}$,

- fejmagasság - tényező: 1 ,

- lábhézagtényező: 0.25 ,

-fogszám:18,

- profileltolási tényező: 0 .

Bevezettük a fajlagos maximum sugárértéket (0.38). A fajlagos maximum sugárérték az $1 \mathrm{~mm}$ modulú fésűskés maximális lekerekítési sugara, amit „rcs”-vel jelöltünk.

Bevezettük a lekerekítésisugár-szabályzó tényezőt: amelyet $\Psi_{r}$-vel jelöltünk. A $\Psi_{r}$ értéktartománya 0.1 közötti érték. Jelen esetben 0,79-et használtunk.

Az ábrázolás során észleltük, hogy a $\varphi$ futóparaméter eléri a $90^{\circ}$ értéket, emiatt az egyenletben megjelenő $\operatorname{tg}(\varphi)$ értelmét veszíti, ezért a foglábgörbét 3 részből állítottuk össze. Első esetben a $\varphi<90^{\circ}$ értékekre, ezt követően a értékekre, majd a $\varphi=90^{\circ}$-ra kiszámolt értékre határoztuk meg a görbe $\mathrm{x}$, y-koordinátáit.

A talpkör pontját analitikusan is meg lehet találni, bár kissé bonyolultabb számítások árán: a geometriai evolvens poláregyenletét összevetjük a burkológörbe poláregyenletével:

$$
\begin{aligned}
& x^{2}+y^{2}=\rho^{2}=r_{b}^{2} \cdot\left(1+\varphi^{2}\right) \\
& x^{2}(\varphi, u(\varphi))+y^{2}(\varphi, u(\varphi))=r_{b}^{2} \cdot\left(1+\varphi^{2}\right) \\
& \varphi \in\left[\varphi_{1}, \varphi_{2}\right]
\end{aligned}
$$

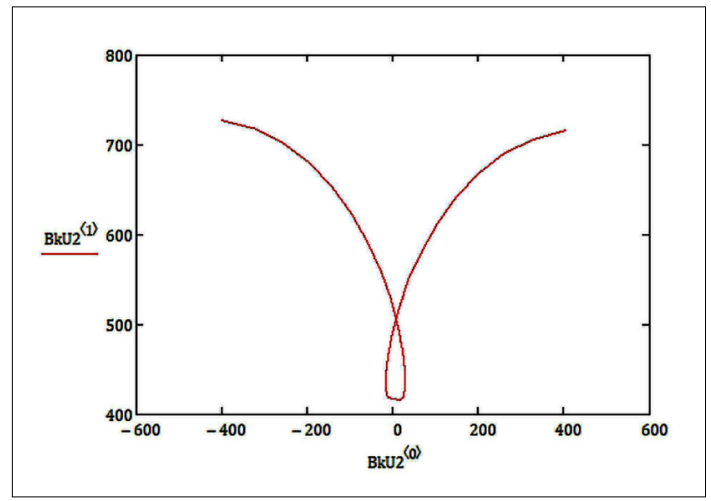

8. ábra. A helyes, szakadásmentes burkolási görbe ábrája

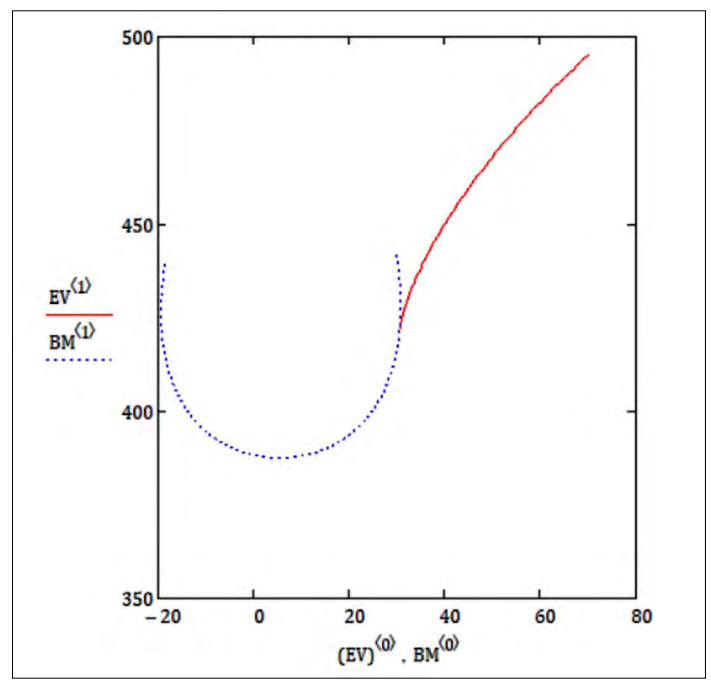

9. ábra. A burkoló evolvens szakasz és a foglábgörbe

Mivel a 9. ábrán látható foglábgörbe kezdeti és végpontja a szükséges szakaszon túlhalad, ezt a programban javítjuk. Eredményként a 10. ábrán látható görbeszakaszokat kapjuk.

A Mathcad-programmal előállított koordinátákat Excel-állományba mentettük, majd beolvastuk az AutoCad-programba. A szükséges körök megrajzolása után a fogprofilt az osztóköri fogvastagság felére és az origóra nézve tükröztük, majd a fölösleges vonalrészeket eltávolítottuk, így megkaptunk egy teljes fogat és a lábkört amelyet a 11. ábrán láthatunk.

A lábkör és a foglábgörbe csatlakoztatásakor észlelt $1 \cdot 10^{-6}$ nagyságrendű hibát a lábkör megnövelésével kompenzáltuk. A terhelésanalízisnél ez a hiba elhanyagolható különbséget jelent. 


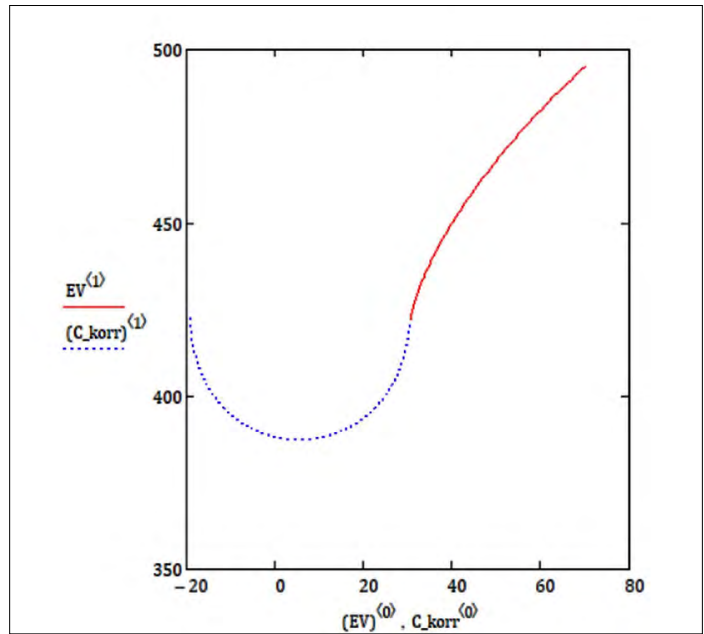

10. ábra. A végső evolvens és lábgörbe profil

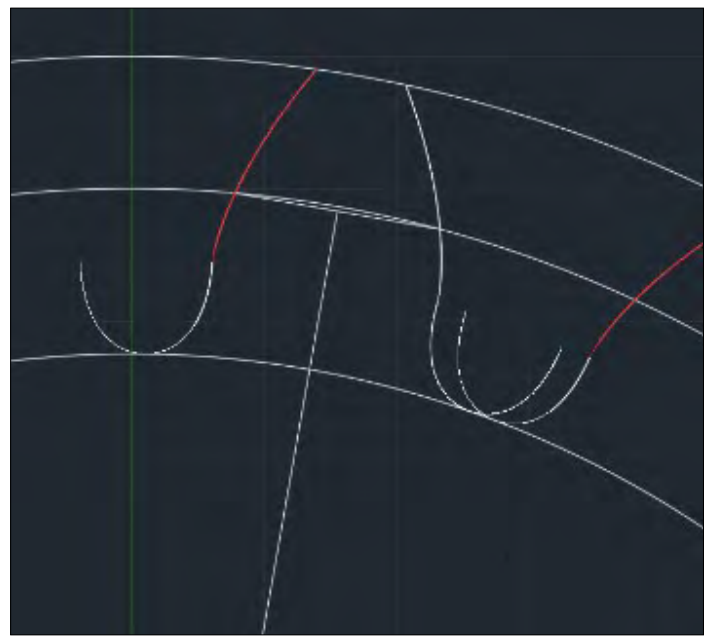

11. ábra. Az AutoCad-programmal generált profil

A rajzmodellt az AutodeskInventor programban testmodellé alakítottuk. A két programcsomag közötti kommunikációs hiba miatt az Autocadből átvett profilt az Inventor program nem folytonos felületként értelmezte, ezért a profilt simítanunk kellett. Ezt az Inventor programban nem sikerült elvégeznünk.

Ezt a lépést a SolidWorks program segítségével végeztük el; ami a profilt $1 \cdot 10^{-6}$ pontossággal simította, és összefüggő felületet készített belőle (13. ábra).

\section{A szabványoknak megfelelő fog ter- helési analízise}

A gyakorlatban a lefejtő szerszám fogoldal és fejszalag találkozásánál megjelenik egy kis leke-

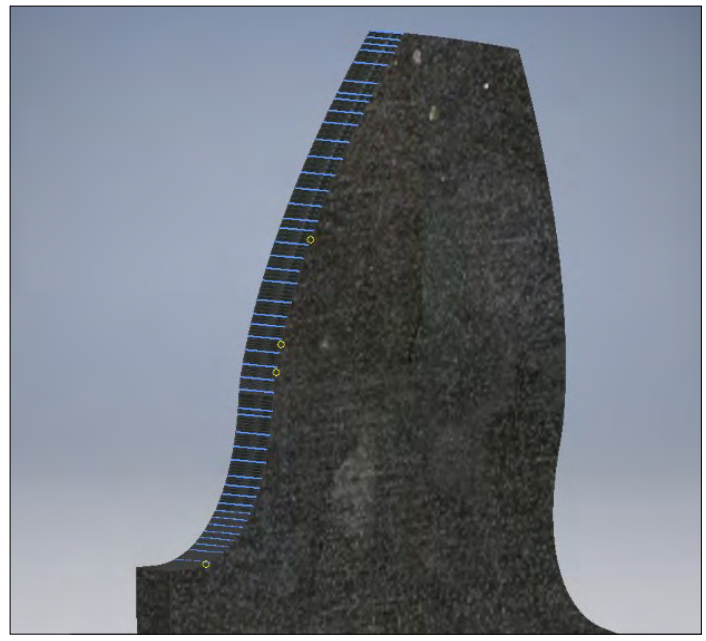

12. ábra. A fogfelület több apró felületből áll

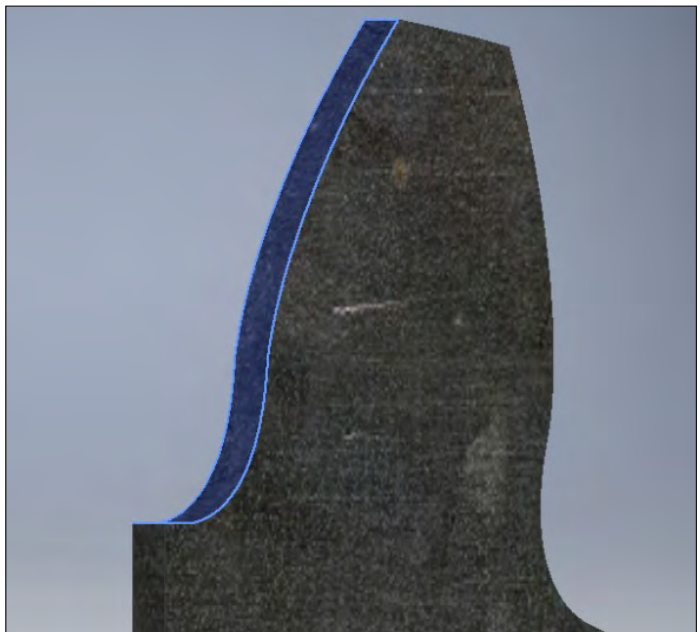

13. ábra. Folytonos fogfelület spline görbével közelítve

rekítés, amit 0,02 mm sugarú körívnek vettünk a modellezés során. Az előbbiekben felhasznált matematikai modellt alkalmazva elkészítettük a Mathcad programban a profilt, majd az Inventor környezetben elkészítettük a testmodellt, Solidworks környezetben simítottuk a profilt, amit 0,000456 mm eltéréssel készített a program. Ezt követően az Inventor környezetben elkészítettük a terhelésvizsgálatot, a fogaskerékszeletet a körből kimetszett $\mathrm{V}$ alak két oldalán mereven befogott oldalként definiáltuk, majd a legkedvezőtlenebb esetet feltételezve, azaz az erőt a profil csúcspontjába helyezve terheltük.

A vizsgálati eredmények a 14. és 15. ábrán láthatók. 


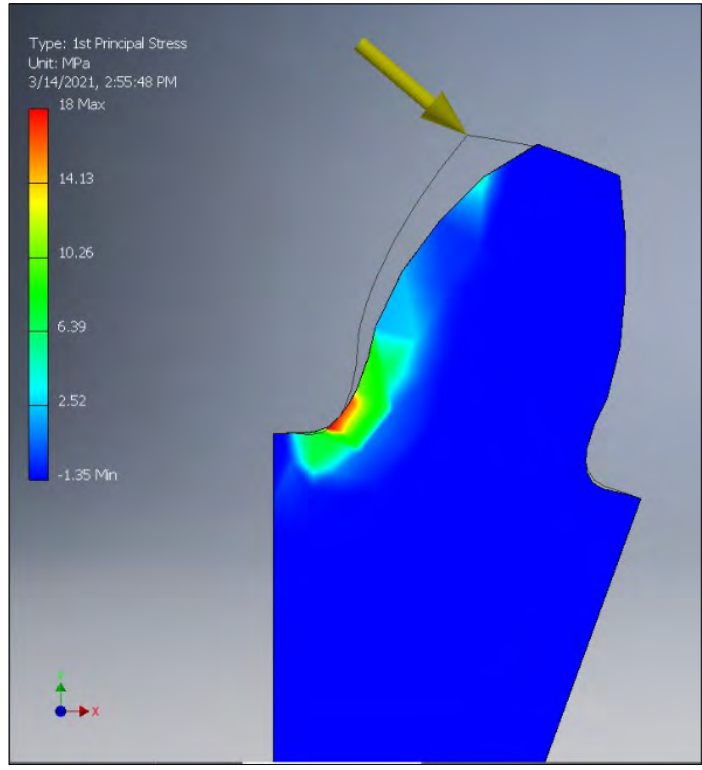

14. ábra. Az első föfeszültség eloszlása

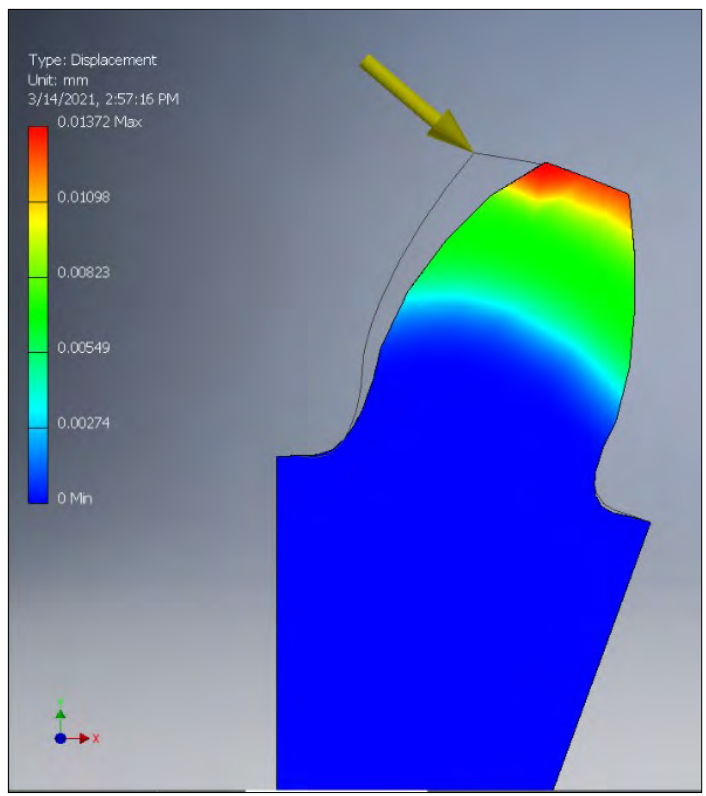

15. ábra. A legnagyobb elmozdulások ábrázolása

\section{A javasolt lekerekítéssel generált fog terhelési analízise}

A javasolt, nagyobb lekerekítésű szerszámmal kapott foglábgörbével épített fogmodellt azonos körülmények között terheltük. A terhelésvizgálat eredményeit a 16. és 17. ábrán szemléltettük.

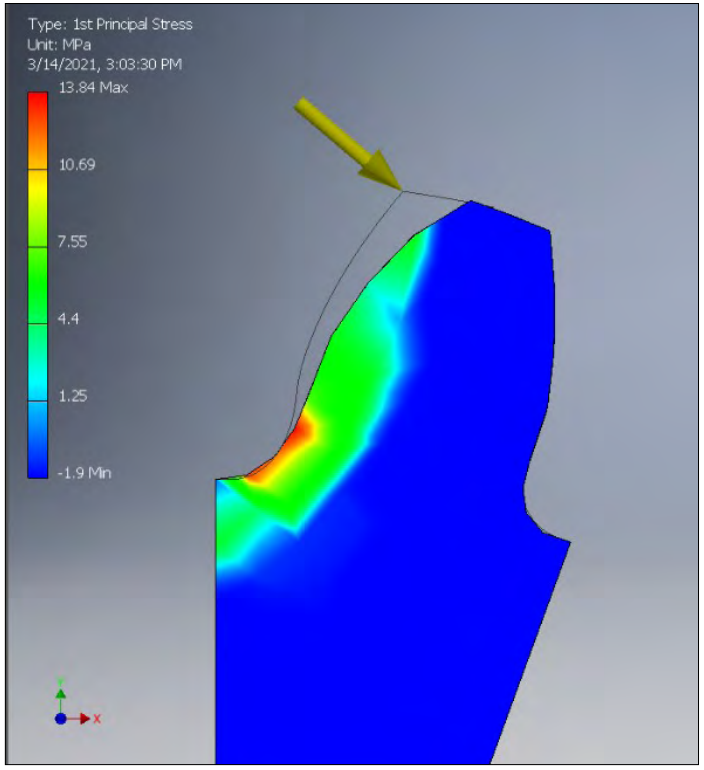

16. ábra. Az első fôfeszültség eloszlás

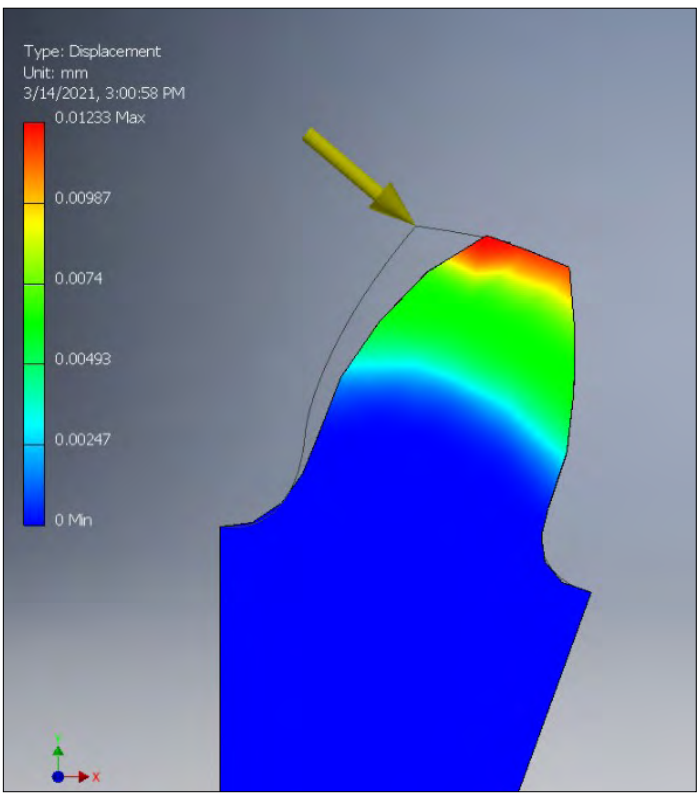

17. ábra. A legnagyobb elmozdulások ábrázolása

\section{Következtetések}

A feszültségeloszlás és az elmozdulások megfelelő ábráit összehasonlítva megfigyelhetjük, hogy adott irányú és nagyságú terhelőerő mellett, azonos rögzítési bázisfelületeket használva, a fog legnagyobb elmozdulása 10\%-kal csökkent. Jelen esetben a fogazás során általános és egyszerü, 
profileltolás nélküli kerekeket elemeztünk, de vélhetően a maximális profileltolást alkalmazva még ennél is jelentősebb mértékű különbségeket figyelhetünk meg.

Az első főfeszültségeket ábrázoló 14., illetve 16. ábrákon megfigyelhetjük, hogy a szabványos profil esetében a maximális feszültség értéke a fogtőben $18 \mathrm{MPa}$, míg a javasolt görbével 13,84 MPa. A fogoldalon a feszültség eloszlása sokkal egyenletesebb a javasolt görbét alkalmazva.

A maximális elmozdulásokat ábrázoló 15., illetve 17. ábrákon láthatjuk, hogy a szabványos profil esetében a maximális elmozdulás $0,01372 \mathrm{~mm}$, míg a javasolt foglábgörbével, csak 0,01233 mm, tehát az elmozdulás értékét 10\%-kal csökkentette a javasolt görbe.

\section{Szakirodalmi hivatkozások}

[1] Máté M.: Hengeres fogaskerekek gyártószerszámai. Erdélyi Múzeum-Egyesület, Kolozsvár, 2016. 110-111.

https://doi.org/10.36242/mtf-12

[2] Litvin F. L.: A fogaskerékkapcsolás elmélete. Müszaki Könyvkiadó, Budapest, 1972.

[3] Hodgyai N, Tolvaly-Rosca F., Máté M.: Az alámetszés körülményei lekerekített gyártó fogasléc esetében. Müszaki Tudományos Közlemények, 14. (2020) 30-36.

https://doi.org/10.33895/mtk-2021.14.05

[4] Szeniczei L.: Az általános fogazás. Műszaki Könyvkiadó, Budapest, 1955.

[5] Tolvaly-Roșca F., Máté M., Forgó Z., Kakucs A.: Development of Helical Teethed Involute Gear Meshed with a Multi-Edge Cutting Tool Using a Mixed Gear Teeth Modeling Method. Procedia Engineering, 181. (2017) 153-158.

https://doi.org/10.1016/j.proeng.2017.02.421. 